DARIA MOROZOVA,

National Dragomanov Pedagogical University (Kyiv, Ukraine)

e-mail:morozovadaria@duh-i-litera.com,ORCID 0000-0001-5646-2851

\title{
MELOS OF THE UNDIVIDED CHURCH. NOTES ON THE INTERCHURCH RESEARCHES OF EARLY MUSIC
}

\begin{abstract}
New attention towards the ancient Church chant is especially on time in today's Ukraine, where the renewed autocephalous Church is entering the global Christian community, looking back at its own historical and liturgical roots and trying to overcome the stereotypes about its tradition. The present article deals with the myths of different Christian musical traditions concerning themselves and their neighbors. Such myths implicitly express the yearning for the lost unity of the Church and condemn the Other for this loss. Hence they continue the dogmatic polemics in the domain of aesthetics. As we have demonstrated, such myths were constructed by the $19^{\text {th }}-20^{\text {th }}$ centuries historiographies of Church chant as an ideological impetus for the renewal of the relevant traditions. However "positive" mythologization of one's own chanting tradition, firstly, retouched those dimensions of its image that were underestimated at that time, and secondly, often denigrated the neighbor traditions. So, the one-sidedness of such mythologization has provoked some modern cantors to engage into the joint reconstruction of authentic history of music together with their foreign colleagues. In this paper such collegial reconstructions - theoretical as well as practical were for the first time assessed as an important dimension of interconfessional and interchurch dialogue. As we tried to show, they are not less necessary than the discussions in dogmatic field and their fruits are much more powerful than any "musical Esperanto" of popular Christian hymns.
\end{abstract}

Keywords: hymnography; Znamenny chant; Byzantine chant; Gregorian chant; semiotics of music; interchurch dialogue.

\section{Introduction}

Ecumenical movement is usually understood as looking forward to future uniting of Christians, but it may be also comprehended as a backward movement of longing for the original melos of Christian liturgy. The revolutionary developments in Ukrainian Orthodoxy, the entry of the new autocephalous Church of Ukraine into the context of universal Orthodoxy, and its introduction as an independent subject into dialogue with Western Christians, prompted an interest in its own liturgical and chanting traditions, a desire for reform, and an aspiration for a liturgical revival. But here the renewed Ukrainian Church was immediately confronted with the myths insinuating the inferiority complex - in particular, the myths of its chanting traditions, which either dissolve the Kyiv tradition in the Muscovite one or simply dismiss it as lower-ranking or heretical. Studies of Ukrainian Musicologists Y. Yasinovsky, N. GerasimovaPersyds'ka, A. Tzalay-Yakimenko etc. systematically dismantle these myths by demonstrating, on the one hand, the rootedness of the Ukrainian musical tradition in Orthodox culture, its connection with the traditions of other Orthodox Churches, and on the other hand, its originality and creative mastery of the Western achievements. However, the myths are not so easily deconstructed.

Purpose and methods

In this paper we are going to deal not with the musicological issues as such, but with the myths themselves that express the general preconceptions of the Orthodox traditions towards their neighbors (including Ukraine). That is why we need comparative-historical approach pertinent to the methods of the American school of History of Tradition and post-Soviet discipline of Culturology. The task of deconstructing the myths is also connected with reviewing the existing experience of such deconstruction. So we will consider the tradition of overcoming the myth, with is a bright feature of the modern liturgical revival throughout the world.

Through the series of examples - mutual reproaches of Latin and Greek specialists in Byzantine Chant, Western idealization of the Slavonic chant and Russian mythology of its folklore origin, contradictory myths concerning the Ukrainian and Romanian chanting traditions - we will try to demonstrate that the stereotypes about singing may create obstacles for mutual comprehension among Christian cultures not less that the objective dogmatic differences, or even more. We will also show that this is true not only about the interconfessional dialogue, but also about the communication between the local Orthodox Churches. That is why the collegial overcoming of the myths concerning each other's singing becomes, as we will see, an important part of ecumenical communication - both interconfessional and interjurisdictional.

\section{Results}

Interchurch dialogue has rightly been viewed by some of its prominent figures in terms of reflection on the past and thorough investigating one's own origins.

It is noteworthy that the majority of those who, in the nineteenth century, made some contribution to the liturgical movement and perceived the value for Christian reconstruction of returning to sources, were in a way the precursors of 'unionism'. This was the case, though reasons differ, with Newman, Moehler, Dom Pitra and several 
others. - dom Olivier Rousseau wrote in 1945, - and this same thing recurs in the twentieth century. Ecclesiology and liturgy necessarily lead to the problems of division and unity (Rousseau, 1951: 148).

Yearning of the Catholic liturgists for the voice of the ancient undivided Church is known also to the Orthodox. Let us reflect here on this paradox: why the aspirations for the future unity are cherished by the view into the past - in particular, the liturgical past - however dramatic could it be.

In his article on the "two Ecumenisms" Andrey Shishkov (2017) describes the disappointment in the Ecumenism as a late Modern project, aiming at cancelling the "remnants of the old times", renewal of the language of dogmatics and creating some new and universal Church culture. On practice, this project fails to obtain the wide reception on the side of traditionalist Orthodox society and do not reach beyond rather limited circle of theologians. At the same time the Orthodox do eagerly support the Postmodern trend that A. Shishkov defines as "conservative Ecumenism" or the Ecumenism 2.0, where the common ground for the interconfessional communication is conditioned by the mutual vivid concern with the Christian tradition. The author refers mostly to the social projects of this sort, like the Christian-right movements, Pro-Life activities etc., ${ }^{1}$ - however that is not all that may be said on "conservative Ecumenism". Doubtlessly, we may also connect with it the conjoint researches of the Church tradition (more precisely, traditions), which let us find out carefully their most important and authentic aspects and deconstruct the mythological stereotypes, in particular those about the neighbor's piety and culture. The latter aspect is especially significant for the Orthodox mentality, where aesthetics has much more weight than politics or law.

\section{The myths on the neighbors' singing}

The hymnography of the ancient Christian cultures is interrelated not only typologically but also genealogically. The Byzantine chant (with its Balkan variants) and Znamenny chant of Ancient Rus' both have as their common root the early Greek chant which originates from the antique and primitive Christian music. The same early Greek chant also gave birth to the early Western chants especially Ambrosian ${ }^{2}$, Beneventine and Old Roman chants - that in turn formed the basis for the Gregorian plain chant. The early Greek hymnography itself was greatly influenced by the Semitic tradition (Hebrew and Syriac ${ }^{3}$ ) and is more or less interleaved also with Coptic, Ethiopian, Caucasian ${ }^{4}$ chants. However, as also in the human families, the closer is the kinship of these traditions the worse may be their relations.

Polemics concerning the right way of embellishing the melody were documented as early as in the $4^{\text {th }}$ century there between the two neighbor Churches - of Caesarea and of Neocaesarea (Razumovsky, 1867, vol. 1, p. 12). The modern historiography of different musical traditions often show the nostalgia for the supposed primordial uniformity and reproach towards the other traditions that failed to preserve it. This divergence between the traditions is (silently) perceived as a certain cultural trauma. Such

\footnotetext{
1 He cites the documents like Hartford declaration of 1975 etc. 2 It was St. Ambrose who introduced into the whole Western Church the singing according to the rite of the Eastern Churches. ${ }^{3}$ Especially through St. Ephraim and St. Romanos the Melodist.

${ }^{4}$ For instance, Stanislav Zelinsky cites certain "motifs" (popevki) pertinent for Znamenny chant, which may be found in the Armenian $5^{\text {th }}$ century hymns.
}

myths about the own tradition and the neighbors make a certain continuation of the dogmatical polemics. Therefore, their analysis is not less vivid than the investigation of the mutual accusations in the field of dogmatics.

The bright example of fruitful though ambivalent scholarly mythologisation of the history of music may be found in the works of the Solesmes liturgical movement.

Since 1830-ies, the domain of the liturgical chants became the subject of the intense investigations. During the several decades, it was revealed that singing may play the definitive role in the liturgical unification... These ideas were mostly developed and embodied due to the works of the liturgical laboratory into which turned the Solesmes abbey (Pérès, 2005).

The scholars of this laboratory connected the Gregorian plain chant, that was the ideal in their eyes, with early Greek chant, emphasizing the kinship of Western and Eastern music. However, in the discrepancy of the liturgical traditions, which stroke the eye already in the Middle Ages, they blamed the Byzantine reforms, especially the "liturgical revolution of the $11^{\text {th }}$ century", when the earlier Constantinople notation was changed for the later Jerusalem (Damascenian) one (Thibaut, 1907: 37). Dom Pitra in 1867 lamented about massive changes and reduction of the ancient Typicon by the Greeks - "premier résultat du schism" (Pitra, 1867: 62-64). Half a century later, Thibaut agreed with him, supposing that the "corrupted" Jerusalem Typicon was forced into application in St. Sofia and in the whole Greek Church intentionally, in order to alienate the East from the West. He cited Symeon of Thessalonica $(+1429)$ : "Tout ces changements dans nos vénérables coutumes liturgiques n'ont pas d'autre cause que la persécusion des Latins!" 5 . "Hymnes démembrées" et "une rupture vive en tête de tous les canons" (the second song that disappeared from them) figure in the text of dom Pitra as a certain symbol of the schism between the Churches. (It should be noted that in the later works of the Solesmes movement the image of the Byzantine liturgy changes drastically: according to dom Rousseau, "there can be no question of a liturgical movement within the Orthodox Church" because its religious life has always been "in the full contact with the liturgy" (Rousseau, 1951: 140)).

While regarding extremely contemptuously the "barbarian" musical innovations of the Paleologian Byzance ${ }^{6}$, dom Pitra and dom Thibaut, curiously, express very different attitude towards Znamenny chant of the Ancient Rus. Although the Balkan peoples were led by the Greek distortions, the Eastern Slavs "fort religiesement" preserved the ancient notation and saved it from complete vanishing (Thibaut, 1907: 39). Thibaut, a member of Russian Archeological Institute in Constantinople ${ }^{7}$, was sure that despite changes, introduced by "génie particulier du people russe", the early Constantinople neumes could be easily recognized even in the modern kriuki (Znamenny neumes), used by the Old Believers ${ }^{8}$. So, kriuki may be helpful

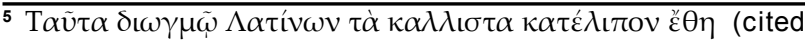
by: Thibaut, 1907: 39).

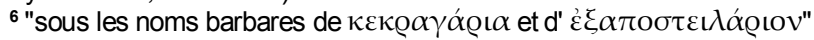
(Pitra, 1867: 62-64); "de fioritures barbares qui sont loin de les embellir" (Thibaut, 1907: 42).

${ }^{7}$ And a friend of Russian researcher of Znamenny chant N. Uspensky.

8 Thibaut calls it "notation de Meznetz", meaning starec Alexander Mezenetz who, not belonging to Old Believers, systematized kriuki notation in the $17^{\text {th }}$ century, in order to preserve it for the New Rite Church (his handbook was published in 1888 by S. Smolensky).
} 
in decoding of the old Greek notation and the early Western neumes which stem from it: St. Gall, Laon, Metz and other notations. ${ }^{9}$

Apparently idealizing the East Slavic culture (that he fails to distinguish from the Russian culture), Thibaut however emphasized the kinship of Znamenny chant with the hymnography of other Christian cultures. On the contrary, among the Russian adherents of the Old Rite became widespread the myth about nearly absolute originality (samobytnost') of this chant, assertedly arising mostly from Russian folk music. Its appearance is often assessed as "a creative feat" of Russian people (Morozan, 1991). Certainly, the Church chant is interleaved with the culture of people in which it exists; nevertheless, this overestimation of the national element is problematic. The melodies, coming from zones of very different folklore - from the Carpathians $^{10}$ to the Russian North - demonstrate amazing resemblance ${ }^{11}$. It testifies about the great conservatism of Stolpovoy ("pillar") Znamenny chant - by contrast with its late $\left(16^{\text {th }}-17^{\text {th }}\right.$ centuries) variants, such as Putevoy, Demestvenny, Large Znamenny, Strochnoy styles ${ }^{12}$. Due to this conservatism, archaism and detachment from any worldly elements (including the folklore) Znamenny chant could not stand competition with the glamour polyphonic chant, and became marginalized during the $18^{\text {th }}$ century. That is why we have at least partly lost the clues to kriuki which might have given us the clue to the most ancient music of Europe.

The myth of the folklore character of Znamenny chant is accompanied by the myth of entirely artificial character of the Ukrainian Church music that reportedly refused from the primordial tradition, preferring to imitate the West. Some view this "fact" as an apostasy, some - as a subject for national pride, but the reality is more complex, as usual. Indeed, the schools of baroque music, orienting on the Western examples, flourished since $17^{\text {th }}$ century in KyivMohyla academy, in Hluhiv and in other Ukrainian centers. They gave a number of outstanding composers (M. Diletsky, D. Bortniansky, M. Berezovsky, A. Vedel) and influenced greatly the tastes of the imperial nobles, - which had the most deplorable consequences for Znamenny chant. However, while the elite were fond of experiments with polyphony, the bulk of the Ukrainian believers (including the Cossacks, who maintained the activity of the brotherhoods) preferred the traditional Znamenny chant. It was known here in a number of local variants - Kyivan, Volynian, Ostroh, Lviv, Supraśl and other styles.

\footnotetext{
${ }^{9}$ In the $11^{\text {th }}$ century these neumes, in turn, formed the basis for the development of the modern staff notation.

${ }^{10}$ Besides the archaic Carpathian chants that exist until now, let us mention here the polish Białystok (ancient Suprasl'), were the earliest staff notes of Znamenny chant were preserved, and the Romanian monasteries of St. Paisius Velichkovsky, which used (among other) Stolpovoy and Kyivan Znamenny chant (according to the old musical manuscripts of Neamt).

11 The parallelism of Western Ukrainian styles with the archaic Stolpovoy chant catches the eye even during a fluent acquaintance with the scores (some of them were published by A. TzalayYakimenko in 2000 in Kyiv). The similarity and differences between these styles are scrutinized by Yury Yasinovsky, Olexiy Tuliuk, Bohdan Zhulkovsky and others.

12 These variants also do not have any immediate connection with the folk music, for they were created by the most famous professionals on the basis of Stolpovoy melody. See (Kutuzov, 2008: 59-78). The artificial character of Strochnoy style was proved by M. Brazhnikov in his unpublished dissertation "Polyphony of Znamenny Scores" (1945).
}

Throughout the $17^{\text {th }}$ century Kyiv-Pechersk lavra was one the main strongholds of the ancient chant in Ukraine. Znamenny irmologions, written in modern notation but hardly diverging from the mediaeval paradigms, were used here until the beginning of $20^{\text {th }}$ century $^{13}$ (although the professional feast choirs proceeded to the Western polyphony already in the $18^{\text {th }}$ century (Herasymova-Persyds'ka, 2012: 22-23)). And even the specific staff notation, widespread in the baroque Ukraine (Kyivan znamia or toporiky, "the axes"), differed from the Western round notes so significantly, that certain scholars even supposed its independent origin ${ }^{14}$. One more important feature of the Ukrainian chants is their connection with the South Slav chants ${ }^{15}$ through the Romanian tradition: "the main artery of spreading of the Balkan repertoire to the East Slavic lands went along Moldavia and Wallachia, through the famous centers of Byzantine vocal tradition - monasteries of Neamt, , Putna, Dragomirna, Suceava" (Yasinovsky, 2001).

Some contrasting views on the Romanian Church music itself are assessed by Costin Moisil (2011). In the $19^{\text {th }}-20^{\text {th }}$ centuries historiography it appeared sometimes as more Byzantine than even the Greek Church music (Macarie, 1823: vii-x; Pann, 1845: xxi-xxviii). Specific sense of piety, "sweetness and smoothness of the melody" of this chant led some scholars to a thought that it was especially close to the ancient Athonite tradition, unlike the Phanariote Greek chant that supposedly departed from it (Petrescu, 1872: 41). However the other researchers emphasized the Turkish, Arabic and even Persian influences on the Romanian music (through the same postByzantine Greek chant) (Ciobanu, 1992, vol. III, p. 194195). Yet other authors marked the specific "taste and genius of the Romanians", presuming "a peculiar national character for chant in Romanian", that was closer to the "civilized and progressive Europe", than to the decadent East (Petrescu, 1872: 41) ${ }^{16}$.

These several examples demonstrate that the stereotypes of singing and stereotypes about singing may create obstacles for mutual comprehension among Christian cultures not less that the objective dogmatic differences, or even more. Moreover, as we have seen, this is true not only about the interconfessional dialogue, but also about the communication between the local Orthodox Churches. That is why "Ce formidable mouvement de réappropriation des musiques anciennes est non seulement une ouverture vers le passé, mais aussi, et peut-être surtout, un prodigieux outil d'ouverture vers d'autres cultures et civilisations d'aujourd'hui" (Pérès, 2011).

\section{Traditions of overcoming the myths}

The desire to renovate an ancient tradition that was lost or distorted at Modern era, was pertinent probably for the whole $20^{\text {th }}$ century Orthodox world. This renaissance

\footnotetext{
13 The irmologions of Lavra are studied by Olena Shevchuk, Olesya Prylepa etc. Some kriuki manuscripts also have survived in several fires, but it is difficult to say how many of them there were initially. See (Zelinsky, 2009).

${ }_{14}$ (Razumovsky, 1867, vol. 2, p. 85) cites "one author of theory of music" without naming him

${ }^{15}$ Although the so called "Greek", "Bulgarian", "Serbian" styles widespread in Ukraine till nowadays are considered as mostly local styles that departed greatly from the chants of the relevant traditions.

${ }^{16}$ (Popescu-Pasãrea, 1940: 21-22) considered that truly Romanian melodies were mostly composed "in the national melody of the first plagal mode" or "the melody of Romanian doinã" (cited by Moisil, 2011: 122-125)
} 
has successfully occurred on Balkans, in Georgia etc. ${ }^{17}$, but not in the Russian Church (and in depending on it Ukrainian, Belorussian, Baltic and other Churches). The latter Churches are still completely dominated by the Western classical polyphonic chant, which was rejected in the Catholic West itself. And, paradoxically, this emotional and pathetic Church music inspires the believers for struggle with that same West in the name of "Holy Rus", whose millennial traditions - especially, hymnography are almost completely forgotten. Thanks to the Old Believers and the other amateurs of the Old Rite ${ }^{18}$, these traditions have never been completely interrupted. But the bulk of the believers still do not know anything about them ${ }^{19}$ and even fail to understand an expression "Znamenny chant".

So, East Slavic Churches are today approximately in that situation, which the Catholic world experienced already in the middle of the $19^{\text {th }}$ century. Then the leading figures of the Western monasticism realized that authentic Christian spirituality is impossible without the return to the ancient liturgical traditions.

"It was about creating a new religious feeling that broke with the two types of aesthetics that had been dividing the Church, - points out Marcel Pérès, - with the 'secular' music (...) and with the aesthetic of liturgical chant, that was inherited from two previous centuries" (Pérès, 2005).

However, the researcher marks the ambiguity of the revolutionary reform gained by the Solesmes movement: the Gregorian plain chant was re-established in the Church, but the cost of this was the replacement of live singing traditions with a unified Gradual of doubtful authenticity (Pérès, 2005).

Just quoted Marcel Pérès today is probably the leading researcher of the melos of ancient Church. He is the director of Ensemble Organum (in Moissac abbey) and of the Itinerant Center for Research on Ancient Music (CIRMA). Since 1982 these institutions have been reconstructing the early notations and manners of singing, investigating theoretically and practically the vocal practices of Church. Moreover, they spread this knowledge, imparting to performers and listeners a taste for forgotten musical treasures and creating in this domain a tradition of reconstructing the Tradition (Pelikan, 1984). It is especially noteworthy that the earliest chants of Western Europe Ambrosian, Beneventine, Ravenna, Old Roman, Mosarabian etc. - have been investigated by them with the help of their Greek colleagues (such as late protopsaltis Lykourgos Angelopoulos) and so interpreted partly through the prism of Byzantine chant. Hardly does this imply that in the late antiquity the Greeks and the Latins chanted in the same way. Rather, Pérès just seeks to compensate for the monological official publications by the dialogue with his foreign colleagues.

"La plus grande attention - he says - doit être portée à I'historiographie, c'est à dire, bien examiner les mots, les concepts, les images, les lacunes, qui constituent le

\footnotetext{
17 Their traditions spread also in the new lands for the Orthodoxy - for instance, in USA, where St. Antony monastery founded in the desert of Arizona by geronta Ephraim of Philotheou shows the unsurpassed example of the authentic Byzantine chant.

${ }_{18}$ Among them such famous (New Rite) Saints as Seraphim of Sarov, Philareth (Drozdov), Ignaty (Brianchaninov), Varsonophy of Optina and many others.

${ }^{19}$ M. Brazhnikov said about Znamenny chant in 1960-es: "Nobody knows it at all, more precisely - nobody wants to know it"; and that is true until now (Brazhnikov, 1975).
}

discours dominant et notre discours personnel lorsque nous évoquons les hommes du passé... C'est doté d'une telle vision qu'il nous faut aller vers les différentes notations musicales pour les interpréter avec une fluidité du regard seule capable de transformer la sinuosité des signes en énergie sonore" (Pérès, 2011).

The similar task is masterfully fulfilled also by the American collective Capella Romana, founded in 1991. Its "name refers to the mediaeval Greek concept of the Roman oikoumene (inhabited world), which embraced Rome and Western Europe, as well as the Byzantine Empire... and its Slavic commonwealth"20. The ensemble focuses at modern Western classics and the Byzantine chant, "the Eastern sibling of Gregorian chant". With the help of Stanford Center for Computer Research in Music and Acoustics, the collective, without leaving USA, could perform the mediaeval Greek music in the simulated acoustics of St. Sophia of Constantinople, - that would be certainly impossible in the real St. Sophia (project "Icons of sound").

Surely, the Orthodox performers also try to reconstruct their ancient chants. Despite the permanent mutual reproaches of Znamenny and Byzantine cantors, the both aesthetics often find common ground in the reconstructions of the $10^{\text {th }}-12^{\text {th }}$ centuries Greek chant, notably by the choir of Vatopedi monastery on Mount Athos and the

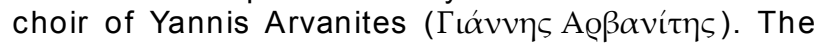
mediaeval South Slavic chants also use to serve as a bridge between the two traditions. Znamenny scores of $16-18^{\text {th }}$ centuries (in kriuki and staff notation) are successfully sounded by a number of ensembles (it is enough to recall the Large Znamenny chant performed by the choir of A. Yurlov in 1960-es, Suprasl chant performed by the choir of A. Grindenko, Ukrainian monodies interpreted by the ensemble of T. Companichenko, choir Kanon, Liturgical centre Peredannya, and so on). However the earlier Znamenny notes (without the "red signs" marking the pitch $^{21}$ ) - and all the more so the $10^{\text {th }}-12^{\text {th }}$ centuries Kyivan kontakarion notation - can not be deciphered with any certainty yet. One of the best ways towards their reading is the comparison with the Constantinople and Western neumes, so this is doubtlessly the task for the international and interchurch researches.

Among the curious experiences of ecumenical interaction between the cantors it is worth to mention the manyyear friendship of the Corsican ensemble A Filetta with the ensemble Georgian voices (ปs nomymo bajöo). These two collectives use to perform together the Corsican and Georgian chants, religious and secular. Similar experiences are possible not only in professional milieu. At the international scholarly conferences one might also hear chants, as well as the presentations. For instance, the participants of the recent patristic colloquy "Providence in the East and in the West", visiting the Orthodox cathedral of Warsaw quite spontaneously started singing the ancient hymns: the Romanian group performed Gentle Light of the Byzantine chant, the Catholics from different countries - Salve regina, and so on. Such marvelous "antiphons" of the conversing confessions, not less than scholarly researches, testify to the kinship as well as the diversity of

\footnotetext{
20 http://www.cappellaromana.org/about-cappella-romana/

21 These marks (kinovarnye pomety) were introduced by Ivan Shaidurov only around 1600 . Notwithstanding, some specialists, as Gleb Pechenkin, do not consider their absence as an obstacle (see our interview with him: http://clement.kiev.ua/ru/node/1070).
} 
Christian theological traditions, - and also to the fact that we do have what to say one another.

Interchurch research of the ancient hymnography has many concrete important tasks: the comparison of the traditions and investigation of the border zones; deciphering of the early Znamenny neumes and Kyivan kontakarion notation; further study of early Byzantine and Western neumes etc. However, its most important mission may be the process of conjoint research itself.

\section{Do we need a musical Esperanto?}

It is usually presumed that in the interchurch communication the ancient hymnography is significantly inferior to the modern music such as "Taize songs", simple and memorable like a pop music. I would, however, dare to point out that these popular hymns reveal close to nothing about any Christian culture. The problem is not in their minimalism, for the ancient Church chants are also minimalist in many ways. The problem is, at first, that this chanting Esperanto is not a native language of any Church, which would mature during the centuries in the hearts of her Saints. It is rather an attempt to construe some new language of Christianity. However, the verbal Esperanto was created in order to facilitate the mutual understanding of speakers of different languages. And the "language" of music is universally available. It is comprehensible for everyone without translation and so can provide much better bridge between cultures than does any verbal translation. That is why any equivalent of Esperanto is not needed in the domain of music.

At second, the modern chants do not provide food for the intellect, they rather exploit the emotions of the believers. The ancient church hymns, on the contrary, are designed in such way that they dispose the worshipers towards the deep reflections on the topics, discussed in them. The mediaeval hymnographers, including many outstanding saints - Ambrose of Milan, Gregory the Great, Ephraim Syrus, Roman the Melodist, John Damascene, Kassia, John Koukouzelis etc. - often expressed their thought of God simultaneously in the letters and in the notes ${ }^{22}$. In their hands the centripetal melody did not distract the mind from the text of the hymn, but rather drawn it into the whirlpool of its meanings. Thanks to its formal musical features the mediaeval hymn provided the space, eager to receive the most complicated philosophic reflections. These features created inside its musical texture the space of orality, where theology became an "aesthetic" - that is sensibly-perceptible - phenomenon. In this way it could reach all the participants of the liturgy: the educated and the illiterate, men, women and children ${ }^{23}$ - all who have ears to hear (Mt.11:15).

These features (that we discussed in detail elsewhere (Morozova, 2011)) include: 1) music notation without the staff, that drawn upon the verbal text only; 2) the free modal structure, where an absolute monarchy of tonic is replaced with the relative gravitation of the several root tones; 3) absent (as in Znamenny and Gregorian chant) or flexible and versatile (as in Byzantine chant) measure

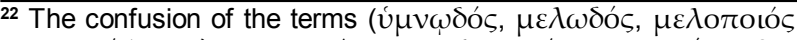

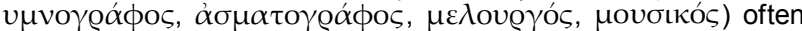
does not allow to guess who is meant - a composer or a poet (Gerzman, 1989: 560). This proves that tradition did not distinguish one from another. See also: (Fotopoulos, 2006: 32).

${ }^{23}$ According to St. Gregory of Nyssa (In inscriptiones Psalmorum, 3 ), it was the melodic form of the Psalms that helped the elderly and the young of each gender and social estate to comprehend King David's theology.
}

signature. Due to these qualities, the ancient hymn was not bounded almost by any musical laws and depended only on the syntax of the thought, expressed simultaneously in words and in their melos.

Thanks to this startling freedom, the ancient hymnography has often inspired the most daring pursuits in modern music - from classics and modern-classics to jazz and art-rock. I will confine myself to the two examples, linked with my native city. Composer Peter Chaikovsky was a great adorer of Kyivan monastic singing; the most wideknown motif of his "Swan lake" is based on the ancient chant "Let all mortal flesh keep silence" from the Irmologion of Kyiv-Pechersk Lavra of $1830^{24}$. In 1971 British progressive-rock group Emerson, Lake and Palmer issued their famous version of not less famous Pictures at an Exhibition by M. Musorgsky (1874), that in turn were created under the influence of Znamenny chant (especially the interlude and piece \#10, devoted to the Golden Gates of Kyiv).

We mentioned the intellectual character of the ancient hymn. However some think that it is not useful to lead the worshipers into reflections on anything besides friendship and toleration, nay on some complex and disputable topics. In this point the advocates of tradition would probably agree with the psychoanalysts that the relations constructed upon concealment of the conflicts and repression of the traumas can not be stable. A house of interconfessional friendship can not stand in the vicissitudes of modernity if this friendship will be devoid of subject. And what else can be the main theme of the interchurch friendship if not the discussions and common researches concerning the chief corner stone of our faith? Christ who suggests us to build solely upon himself (cf. Mt. 7:24; 1Cor. 10:4) is always a weighty topic that is marvelous in our eyes (Ps. 117/118:2223; Mt.21:42). Surely, it may be discussed in cartoons, anecdotes, popular songs - but the "hardcore" of the ancient hymns allows us better to perceive its weight, awesomeness and the foothold that it provides.

An objection may occur that some Church hymns refer to a priory hot topics, such as political questions. To this I can only answer that any political ideas are absolutely foreign to the essence of the ancient Christian hymn as "the theology in sound". Their presence in the liturgics is the result of inadmissible ideological exploitation of this genre. For the canonic hymnography par excellence embodies such feature of the language of music as total absence of reference (bezreferentnost') (Lotman, 1992: 243247).

This problem was widely debated in the 1960-ies and the 1970-ies. A number of Soviet art critics tried - almost in vain - to discover the semantic aspect of music in order to present it as a mouthpiece of social reality. At the same time other semiologists, such as R. Jackobson, M. Dufrenne and $\mathrm{M}$. Wallis, denied the very existence of the "language of music" (sensu stricto), describing it rather as an "asemantic sign". Hence they agreed with the composers like Pierre Boulez concerning the "abstract" character of any music. Having no separate semantic units (like letters and words) (Benvenist, 1974), music appeals to the listener with its whole essence and converses with him on what is known to him alone. It does not inform us about anything - anything transitory, - and exactly for this reason music is able to "utter the Divine Name" (Manoussakis, 2007: 105).

${ }^{24}$ I am thankful for this observation to the late member of our Studio, hieromonk David (Pin'ko) from Kyiv-Pechersk Lavra. 


\section{Conclusions}

So, we have seen that the prejudices of Christians regarding other confessions and even other national traditions are often accompanied by a positive or negative mythologization of their liturgical and, in particular, singing traditions. Thus, the liturgical revival in the Latin Church of the $19^{\text {th }}$ century, focusing on the Roman Catholic identity, extolled its own tradition, simultaneously accusing Byzantium of distorting the chant of the early undivided Church. This trend was opposite to the strong anti-Latin sentiment in the post-Byzantine space. At the same time, Catholic connoisseurs of the Gregorian choral could idealize Old Russian Znamenny Chant, viewing it as the closest to the common roots of Christian music. The modern mythologization of Znamenny Chant as a "creative feat" of the Russian people has its opposite side - the depreciation of Ukrainian church chants. Turning a blind eye to a peculiar Ukrainian medieval singing tradition (preserved in places until the beginning of the $20^{\text {th }}$ century), Russian researchers pay attention only to the so-called "apostasy" of professional music of the Baroque era. However, Ukrainian musicologists also tend to ignore the monodic chants of Cossack Baroque, focusing only on the "Partes" musik. However, this polyphonic music is in fact only one of the facets of old-Ukrainian church singing. Modern scholars observe a similar selectivity in the ratings of the ancient Romanian church chant. Its researchers either viewed it as the purest Athonite heritage worldwide, or criticized it as a fusion of Asian influences, or, on the contrary, praised for its national originality and proximity to the Western music.

Today's efforts to overcome such myths concerning each other's singing do not amount to the search for any sole melos of the ancient undivided Church: such chant hardly ever existed. These are just careful reconstructions of one's own chanting traditions in the dialogue with foreign colleagues, which is always helpful for escaping the limitations of one's immediate cultural context. Such collegial investigations are much more fruitful for any interchurch communication than musical Esperanto like the "Taize songs" which are modern construct and do not refer to any Christian tradition at all. In order to overcome the language of hatred towards each other, we need not to forget the history, but to deepen the authentic mutual understanding. And studying different musical traditions is indispensible for this task, for it reveals the multiple voices of early Christian spirituality, recognizable for all who have ears to hear.

In this way the tradition of reconstructing traditions may unfold to us not only the sources of Christian culture, but also one another. The existing paradigms of such interaction prove that, in the culture of Church, the backward movement of remembering and reconstruction is not at all contrary to the forward movement of development and insight. For it is about the Liturgy which is the "remembrance" of the future Second Coming of Christ.

\section{REFERENCES}

Benvenist, E. (1974). Semiology of language. Obshchaya lingvistika. Moscow, pp. 69-89 (In Russian).

Brazhnikov, M. (1960). Musical manuscripts from the archives of D. Razumovsky and V. Odoevsky. Sobraniya D.V. Razumovskogo i V.F. Odoevskogo. Moscow: 6-22. (In Russian).

Ciobanu, G. (1974 - 1992). Studii de etnomuzicologie şi bizantinologie. In 3 vols. Bucharest. (In Romanian).

Fotopoulos, K. (2006). Introduction into theory and practice of Byzantine Church chant. Glas Vizantii. Moscow. (In Russian)
Gerzman, E. (1989). The Development of Musical Culture. Kultura Vizantii. Vtoraya polovina VII-XII vv. Moscow: 557-571. (In Russian)

Herasymova-Persydska, N. (2012). The specific of the national variant of baroque in the Ukrainian music of $17^{\text {th }}$ century. Muzyka. Vremia. Prostranstvo. Kyiv: Dukh I Litera. (In Ukrainian).

Kutuzov, B. (2008). Russian Znamenny Chant. Moscow, 300 p. (In Russian).

Lotman, Y. (1992). Canonic Art as an Information Paradox. Izbrannye statyi. Vol.1. Tallin, pp. 243-247. (In Russian).

Macarie leromonahul (1823). Irmologhion sau Catavasiery Musicesc. Vienna. (In Russian).

Manoussakis, J. P. (2007). God After Metaphysics. A Theological Aesthetic. Indiana University Press, 213 p. (In English)

Moisil, C. (2011). Romanian vs. Greek-Turkish-Persian-Arab: Imagining National Traits for Romanian Church Chant. Muzikologija, no 11: 119-132. Retrieved from https://www.academia.edu/ 10005622/Romanian_vs._Greek-Turkish-Persian-Arab_Imagining_National_Traits_for_Romanian_Church_Chant (In English)

Morozan, V. (ed.) (1991). One Thousand Years of Russian Church music: 988-1988. Washington. (In English).

Morozova, D. (2011). The Thought of God between the Letters and the Notes. Phenomenology of the Hymn in Antiphon with the Review of Approaches. Koinonia, 950: 313-342 Retrieved from http://www.intelros.ru/pdf/Konoyna/2/14.pdf. (In Russian).

Pann, A. (1845). Bazul theoretic şi practic al muzicii bisericeşti sau Gramatica melodicã. Bucharest. (In Romanian).

Pelikan, J. (1984). The Vindication of Tradition: The 1983 Jefferson Lecture in the Humanities. Yale. (In English).

Pérès, M. (2005). Lecture in Moscow State Conservatoire. 27 of May 2005 (In Russian).

Pérès, M. (2011). L'enseignement des musiques anciennes. Perpectives pour le XXle siècle. Conférence prononcée à Genève, à la Haute Ecole de Musique le 14 janvier 2011 (In French).

Petrescu, I. D. (1872). Arta artelor sau Elemente de istoria musicei. Bucharest. (In Romanian).

Pitra, D. (1867). Hymnographie de l'Église grecque. Dissertation. Rome. (In French).

Popescu-Pasãrea, I. (1940). Evoluția cântãrii psaltice în biserica românã. Cultura 29/3 (In Romanian).

Razumovsky, D. (1867). Church Chant in Russia. In 3 vols. Moscow. (In Russian).

Rousseau, Olivier. (1951). The Progress of the Liturgy. Vancouver. (In English).

Shishkov, Andrey (2017). Two Ecumenisms: Conservative Christian Alliances as a New Form of Ecumenical Cooperation. Gosudarstvo, religiia, tserkov' v Rossii i za rubezhom, 35/1: 269-300 (In Russian).

Thibaut, P. J. (1907). Origine Byzantine de la Notation Neumatique de l'Église Latine. Paris. (In French)

Yasinovsky, Y. (2001). Music of $16-18^{\text {th }}$ centuries. Istoriya ukrainskoy kultury. Kyiv. (In Russian).

Zelinsky, S. (2009). On the 'Angelic Chant' in Kyiv and KyivPecherst lavra. Retrieved from (https://risu.org.ua/ua/index/ monitoring/kaleido_digest/38861/) (In Russian).

\section{LIST OF REFERENCE LINKS}

Бенвенист Э. Семиология языка. Бенвенист Э. Общая лингвистика. М.: Прогресс, 1974. С. 69-89.

Бражников М. В. Певческие рукописи собраний Д. В. Разумовского и В. Ф. Одоевского. Собрания Д. В. Разумовского и В. Ф. Одоевского. М., 1960. С. 6-22.

Герасимова-Персидська Н. Специфіка національного варіанту барокко в українській музиці XVII ст. Герасимова-Персидская Н. Музыка. Время. Пространство. К.: Дух і Литера, 2012.

Герцман Е. В. Развитие музыкальной культуры. Культу- 
ра Византии. Вторая половина VII-XII вв. М.: Наука, 1989. C. 557-570.

Зелинский С. Об ангельском пении в Киеве и Киево-Печерской Лавре. К., 2009. URL: https://risu.org.ua/ua/index/ monitoring/kaleido_digest/38861/

Кутузов Б. Русское знаменное пение. М.: Андрей Рублев, 2008. 300 c.

Лотман Ю. М. Каноническое искусство как информационный парадокс. Лотман Ю. М. Избранные статьи. Т.1. Таллинн, 1992. С. 243-247.

Тысяча лет русской церковной музыки: 988-1988 / Морозан В. (ред.). Washington, 1991.

Морозова Д. Мысль о Боге между буквами и нотами. Феноменология гимна в антифоне с обзором подходов. Койнония. Вестник ХНУ им. В.Каразина. 2011. № 50. С. 313-342.

Перес М. Лекция в Московской государственной консерватории. 27 мая 2005.

Разумовский Д. Церковное пение в России. М., 1867. 3 т.

Фотопулос К. Введение в историю, теорию и практику византийского церковного пения. Глас Византии. М., 2006.

Шишков А. Два экуменизма: консервативные христианские союзы как новая форма экуменического взаимодействия. Государство, религия, церковь в России и за рубежом. 2017. 35/1. С. 269-300.

Ясіновський Ю. Музика (XVI-XVIII ст.). Історія української культури. К., 2001.
Ciobanu G. Studii de etnomuzicologie şi bizantinologie. 3 vols. Bucharest, 1974 - 1992.

Macarie Ieromonahul. Irmologhion sau Catavasiery Musicesc. Vienna, 1823.

Manoussakis J. P. God After Metaphysics. A Theological Aesthetic. Indiana University Press, 2007. 213 p.

Moisil C. Romanian vs. Greek-Turkish-Persian-Arab: Imagining National Traits for Romanian Church Chant. Музикологија. 2011. 11. p. $119-132$.

Pann A. Bazul theoretic şi practic al muzicii bisericeşti sau Gramatica melodicã. Bucharest, 1845.

Pelikan J. The Vindication of Tradition: The 1983 Jefferson Lecture in the Humanities. Yale, 1984.

Pérès M. L'enseignement des musiques anciennes. Perpectives pour le XXle siècle. Conférence prononcée à Genève, à la Haute Ecole de Musique le 14 janvier 2011.

Petrescu I. D. Arta artelor sau Elemente de istoria musicei. Bucharest, 1872.

Pitra D. Hymnographie de l'Église grecque. Dissertation. Rome, 1867.

Popescu-Pasãrea I. Evoluția cântãrii psaltice în biserica românã. Cultura. 29/3 (1940).

Rousseau Olivier. The Progress of the Liturgy / tr. by the Benedictines of Westminster Priory. Vancouver, 1951.

Thibaut P. J. Origine Byzantine de la Notation Neumatique de l'Église Latine. Paris, 1907.

Дар'я Морозова,

Національний педагогічний університет імені М. П. Драгоманова (м. Київ, Украйна)

e-mail: morozovadaria@duh-i-litera.com,ORCID 0000-0001-5646-2851

\section{МЕЛОС НЕРОЗДІЛЕНОЇ ЦЕРКВИ. ПРИМІТКИ ЩОДО МІЖЦЕРКОВНИХ ДОСЛІДЖЕНЬ РАННЬОЇ МУЗИКИ}

Нова увага до древнього церковного співу особливо актуальна нині, коли оновлена автокефальна Церква України приєднується до світової християнської громади, оглядаючись на власні історичні та богослужбові корені та намагаючись подолати стереотипи щодо своєї традиції. Ця стаття стосується міфів різних християнських музичних традицій щодо себе та своїх сусідів. Такі міфи імпліцитно виражають тугу за втраченою єдністю Церкви та осуд Іншого за цю втрату. Отже, вони продовжують догматичну полеміку в області естетики. Як ми продемонстрували, такі міфи фігурували в історіографіях церковного співу XIX-XX ст. як ідеологічний поштовх для оновлення відповідних традицій. Однак "позитивна" міфологізація власної традиції співу, поперше, ретушувала ті виміри її образу, які були недооцінені на той час, по-друге, часто принижувала сусідські традиції. Відтак, однобічність такої міфологізації спонукала деяких сучасних фахівців долучитися до спільної реконструкції автентичної історії музики разом із зарубіжними колегами. У цій роботі такі колегіальні реконструкції - як теоретичні, так і практичні - вперше були оцінені як важливий вимір міжконфесійного та міжюрисдикційного діалогу. Як ми намагалися показати, вони не менш необхідні, ніж дискусії в догматичній галузі, а їх плоди набагато потужніші, ніж будь-яке "музичні есперанто" популярних християнських гімнів.

Ключові слова: гімнографрія; знаменний спів; візантійський спів; григоріанський хорал; семіотика музики; міжцерковний діалог.

(c) Morozova Daria

Надійшла до редакції: 13.09.2019

Прийнята до друку: 02.10.2019

СХІД № 5 (163) вересень-жсовтень 2019 р.

ISSN 1728-9343 (Print) ISSN 2411-3093 (Online) 